\title{
Identification and Crisis: An Exploration Into the Influence of Sports Identification on Stakeholder Perceptions of Sports- Related Crisis
}

Jennifer L. Harker

West Virginia University, jennifer.harker@mail.wvu.edu

Follow this and additional works at: https://researchrepository.wvu.edu/faculty_publications

Part of the Communication Commons, and the Sociology Commons

\section{Digital Commons Citation}

Harker, Jennifer L., "Identification and Crisis: An Exploration Into the Influence of Sports Identification on Stakeholder Perceptions of Sports-Related Crisis" (2019). Faculty \& Staff Scholarship. 1183.

https://researchrepository.wvu.edu/faculty_publications/1183

This Article is brought to you for free and open access by The Research Repository @ WVU. It has been accepted for inclusion in Faculty \& Staff Scholarship by an authorized administrator of The Research Repository @ WVU. For more information, please contact beau.smith@mail.wvu.edu. 


\title{
Identification and Crisis
}

\author{
An Exploration Into the Influence of Sports Identification \\ on Stakeholder Perceptions of Sports-Related Crisis
}

JENNIFER HARKER

This research examines sports identification as relational history with sports entities to test its predictive influence on stakeholders' perceptions regarding sports-related crises. Sports identification was explored as both a social identification with sport (fandom) and as an individual identification with sport (fanship). Results suggest that sports identification is indeed a predictive element to stakeholders' crisis perceptions; however, findings track in an interesting new direction that extends crisis communication theory in sport and suggests that sports crises are perceived in a similar manner to sports rivalries.

Keywords: sports identification, sports crisis, stakeholder perceptions, sports rivalry

\section{Introduction}

Sport offers a heightened environment for the study of crisis. Stakeholders of sports entities possess strong opinions on any number of things regarding their beloved sports team or favorite athlete. Overt, highly identified fans seemingly turn a blind eye to social or moral wrongdoings, like domestic assault or cheating, by continuing to tune in and cheer after such transgressions are carried out by their favorite teams and athletes.

Sports organizations experience crises just as other types of organizations experience crises, and sports organizations and athletes possess as much need to protect their reputation as any other celebrity entity (Kruse, 1981; L'Etang, 2006, 2013; L'Etang \& Hopwood, 2008). The types of crises differ for sport, however. Traditional organizational crises include product failures and recalls or a financial downfall, whereas crises in sport include health and safety concerns like concussions, drug abuse, violent acts such as domestic assault, cheating, or even athlete activism that spurs politically polarized discourse.

Crisis research regarding sport has focused on retrospective, rhetorical analyses deep diving into crisis remediation attempts. Research has extended 
these retrospective analyses to include fans' remediation attempts via social media on behalf of a sports entity (N. A. Brown \& Billings, 2013), but we still have not yet asked whether fans perceive crises in sport in a similar manner as stakeholders perceive crises regarding traditional organizations. For example, would a customer continue to do business with a company that sold a defective or even harmful product or service? Probably not. What mechanisms shelter sport in such a way that no matter the social or moral wrongdoing, fans continue to tune in instead of tuning out?

This research argues that relational history is the factor that differs between crises in sport and crises in traditional organizations. Situational crisis communication theory suggests that a positive prior relationship with stakeholders can act as a buffer (Coombs, 2007a; Koerber \& Zabara, 2017) or offer a halo effect (Coombs \& Holladay, 2006) during times of crisis. This positive prior relationship reduces negative stakeholder perceptions and allows an organization to more quickly recover from the crisis. In sport, fans are also defending the reputation of their beloved team or athlete by engaging in remediation attempts. Why would fans aid sports organizations in remediating crises? This research extends the sports crisis communication literature by examining this theoretical component of relational history as sports identification and testing that component alongside crisis perceptions among sports fans.

This research rests at the praxis of sport, crises, and identification in the context of the National Football League (NFL) in an effort to conceptualize and test the theoretical relationships among stakeholders' crisis perceptions and sports identification. This research investigates stakeholders' crisis perceptions regarding four crises that occurred or are ongoing involving the NFL: concussions, cheating, domestic assault, and the highly publicized \#TakeaKnee movement. Stakeholders' crisis perceptions were captured via an online survey and the calibrating propensity of sports identification was measured in relation to the severity of crisis perceptions. Next, a review of the crisis communication literature and the theoretical basis of this research are presented before more fully explaining the method carried out in this research.

\section{Literature Review}

Traditionally, public relations scholars use one of two theoretical frameworks to conduct crisis communication research. Image repair theory (Benoit, 2015) is a theoretical, rhetorical lens used to decipher the application of crisis remediation strategies. Retrospective case studies of crisis situations

I72 Journal of Sports Media, Vol. I4, Nos. I-2, Spring-Fall 2019 
often use this framework to identify the strategies a communicator used in self-defense following a crisis event (Avery, Lariscy, Kim, \& Hocke, 2010; Harker \& Saffer, 2018). Image repair theory is limited by its one-way communication structure and lacks an ability to assess the direct inclusion and measurement of public perceptions.

Situational crisis communication theory offers a more comprehensive theoretical framework that is quantitatively focused, practitioner applied, and situational in its crisis communication typology (Coombs, 1995, 1998, 2004, 2007a, 2014; Coombs \& Holladay, 1996, 2002, 2006, 2008). Broadly, this theoretical framework reaches beyond simply assessing the crisis types and response strategies and draws from attribution theory (Heider, 1958; Weiner, 1986, 2008) to understand the ways in which stakeholders attribute crisis responsibility in response to a perceived wrongdoing. Crises can relate to an array of issues and have the potential to "seriously impact an organization's performance" (Coombs, 2014, p. 2), generate negative outcomes, and "disrupt or effect an entire organization" (Coombs, 2014, p. 4). Crises are "a threat to relationship," and any threat to relationship "is a threat to the reputation" of an organization (Coombs, 2014, p. 35).

A centerpiece of situational crisis communication theory is providing guidance for the assessment of stakeholders' perceptions. With an interest toward remediating crises, the theory backsteps to explain how attribution of responsibility, the assessment of the crisis situation, and a stakeholders' past experiences with the entity experiencing the crisis all combine to form resultant reputation perceptions during or following a crisis. A stakeholder is any person or group that holds some connected interest with the entity enduring a crisis (Ulmer, 2001). Stakeholders can include other organizations, governmental agencies, the media, and any individual connected or among the general public adjacent to the organization, just to name a few examples (Ulmer, Seeger, \& Sellnow, 2007).

Stakeholders' perceptions are critical components of crisis remediation and an underutilized consideration in sports crisis communication (Billings, Coombs, \& Brown, 2018; Coombs \& Holladay, 2006, 2008). According to situational crisis communication theory, the three stakeholders' perceptions weighed in the assessment of an organization's reputation in a crisis are key to understanding how to overcome a crisis (Coombs, 2007a). The three perceptions include perceived responsibility, which includes attribution and amount of blame, the amount of evidence of the crisis, and whether the crisis was accidental or purposeful; crisis history, which asks whether the crisis was a one-time event or a series of repeated events; and relational history, which is an assessment of past positive transactions between the stakeholder 
and the entity. To better explain, the more a stakeholder believes an organization is responsible for the wrongdoing or the more evidence present to build a case against the organization, which can be multiplied by the number of times the wrongdoing was allowed to occur, the lower the resultant reputational assessment during or following the crisis (Coombs, 1995). However, generally speaking, a prior positive perception held by the stakeholder regarding the organization can serve as a buffer when a crisis occurs, thus reducing anger and blame (Coombs, 2007a), although that is not always the case across all experiments testing for buffers (Sohn \& Lariscy, 2012).

Past research has suggested that stakeholders' crisis perceptions can be calibrated by overall experiences and personal connectedness to the entity experiencing the crisis (Coombs, 2007a), and this is an understudied facet in the sports crisis communication literature. A buffer can be conceptualized as a "pre-existing factor that could influence" the perceptions surrounding a crisis (Koerber \& Zabara, 2017, p. 194). Buffers result in less serious crisis perceptions because of emotional or proximal perceived connections with the entity in crisis (Koerber \& Zabara, 2017). In other words, an individual interprets a crisis via a kaleidoscope of perceptions, and those perceptions shape blame attribution and, ultimately, reputational assessment. The culmination of stakeholders' perceptions, past experiences or exchanges, and crisis attribution are as unique as the individual assessing the crisis. For these reasons, personal identification with the entity in crisis should be measured because perspective can play a key role in crisis perceptions (Coombs \& Holladay, 2006).

Positive perceptions of crisis events are not often studied in the crisis communication literature. In fact, positive crisis perceptions may seem counter to traditional crisis communication research. Yet it is argued here that such exploration is important to consider, especially when weighing the crisis assessment factors in the situational crisis communication theory model. Not all stakeholders negatively perceive a crisis or attribute responsibility to the entity enduring a crisis. There are crises perceived as valuable or positive, depending on an individual's perspective or how a person might identify with the entity or the crisis.

This research is situated within the three stakeholders' perceptions assessment factors-perceived responsibility, crisis history, and relational history. This research explores the continuum of crisis valence and applies the three assessment factors specifically to sports-related crises and perceptions of sports fans. The following research question relating to stakeholders' perceptions is first posited: 
RQ1: What are the crisis perceptions among NFL stakeholders regarding NFL crises?

This research examines whether sports identification, be it social identification with sport or an individual identification with a specific NFL team (Tajfel \& Turner, 1979), possesses any predictive influence over crisis perceptions in sports-related crises. Identification can vary in intensity and duration, and identification can spur cognitive, emotional, and behavioral outcomes (W. J. Brown, 2015; Moyer-Gusé, 2015). For these reasons, sports fandom and sports fanship, two forms of sports identification that also vary in intensity resulting in emotional and behavioral outcomes, are explored. The next section provides an overview of both forms of sports identification and the proposed importance of measuring fandom and fanship when assessing sports-related crisis perceptions.

\section{Sports Identification}

Relationships and perceptions are individual interpretations developed via a kaleidoscope of personal experiences, feelings, and involvement or engagement over time. In other words, the culmination of experiences with an organization or individual is as unique as it is individualized, and those past experiences help an individual form perceptions and feelings related to that organization or individual. That connectedness that forms over time (i.e., relational history) includes identification, which by definition is a sense of identity with someone or something meaningful to oneself.

Fandom and fanship have proven important measurements in sports communication research examining sports fans' propensity to engage with sport and in the assessment of their reactive behaviors to sport and sportsrelated outcomes (Billings, Qiao, Brown, \& Devlin, 2017; Spinda, 2011). Fanship and fandom are measurements of an individual's personal or group identification, or relational history, with sport. The study of connectedness to sport spans a continuum from the psychology of self at the individual level to the sociological shared identity with other fans at the group or social level. This study harnesses that continuum by dichotomizing the individual identification (fanship) and the social identification (fandom) considerations of sports connectedness (Reysen \& Branscombe, 2010; Wann \& Branscombe, 1993).

Translating identification into being a fan of a sport or a particular sports team relates to an individual's psychological connection to a particular sport or sports team (Kruse, 1977, 1981; Wann, Melnick, Russell, \& Pease, 2001). 
For some, that identifying connection grows stronger than for others, and scholars have called for a rank ordering of identification in sport to range from a casual fanship to a "primary social identity" (Hirt \& Clarkson, 2011, p. 3). Put simply, identification with sport varies by individual and social levels of identification. A review of the measurement of sports identification at these levels are operationalized in the sections to come. First, an explanation of the connectedness of social identification and sport is offered.

Individuals work toward a positive social identity and avoid a perceived negative social identity by connecting oneself to or distancing oneself from what is perceived as a favorable in-group and a comparative out-group (Tajfel \& Turner, 1979; Weiner 1986, 2008). When a social in-group identity is challenged in any negative manner-such as a losing season in sport, for example-efforts are taken to "differentiate" oneself or one's group (Tajfel \& Turner, 1979, p 40). This differentiation occurs either by leaving the in-group or reshaping the in-group to be viewed more positively than a comparative out-group (Tajfel, 1982). When such dissonance occurs, people collectively close that cognitive gap by highlighting the positive attributes of the ingroup and blasting the negative attributes of an out-group (Cialdini \& Richardson, 1980; Tajfel \& Turner, 1979). To translate this to sport, a football fan might minimize a loss with accusations that the rival team cheated or that the referees were particularly strict that day.

Fandom. Fandom has been used synonymously and interchangeably with fanship in sports studies. Webster's dictionary defines fandom as "being a fan of a particular person, place, or thing regarded collectively as a community or subculture." Wann (2006) defines a fan as a follower of sport, someone who is actively interested in and engaged with sport. The word fan is a derivative of fanatic, Wann (2006) noted, which puts an "emphasis on emotion over knowledge" (Hirt \& Clarkson, 2011, p. 2). Sports fans have been operationalized as those who report high amounts of enjoyment from sport, consume sports media for an hour a day or more, and actively seek out sports-related information (Gantz, Wang, Paul, \& Potter, 2006).

Fandom is a social or group identification with other fans, with a nod toward a collective esteem (Dietz-Uhler \& Murrell, 1999; Reysen \& Branscombe, 2010). In other words, fandom is a group-related identification attempt to attach oneself to a positively perceived group. Reysen and Branscombe's (2010) work is the most precise distinction to date in dichotomizing social and individual identity. For example, the authors inductively quizzed college students about general hobbies and ended up with an 11-item scale. The authors noted differences they found between a social identity with others who enjoy the same or similar hobbies and 
an individual identification with the favorite hobby. This is one of many examples relating the need for precise dichotomization between individual identification and social identification. This research explores that gap by measuring both. Individual-level identification is discussed next.

Fanship. Fanship is described as a continuum from no identification or connection at all to high identification and close connectedness (Gantz et al., 2006; Wann \& Branscombe, 1993) and "represents an array of thought processes, affective attachments, and behaviors that separate fans from nonfans" (Gantz et al., 2006, p. 96). The most widely used scale in the sports communication literature to measure sports fanship has been the Sports Spectator Identification Scale [SSIS] (Wann, 1995; Wann \& Branscombe, 1993). SSIS originally investigated an individual's collegiate basketball team identification. The items capture fan behaviors and how much a sports fan identifies, or perceives their identification, with a particular team. SSIS has since been applied across numerous conceptual sports studies and in combination with other psychological and behavioral sports-related research (Billings, Qiao, et al., 2017; Brown-Devlin, Devlin, \& Vaughan, 2017; Spinda, 2011).

Identification is applied in this research as a linking mechanism that relates to relational history in crisis assessment, as well as to the resultant stakeholders' perceptions of a sports-related entity or actor experiencing a crisis. Identification is measured as both fanship and fandom to capture both levels inherent in sport: individual identification and the social identification. Fandom (Reysen \& Branscombe, 2010) and fanship, as expressed by individual identification with an NFL team (Wann \& Branscombe, 1990, 1993), are measured and analyzed alongside stakeholders' perceptions of crisis (Coombs, 2007a, 2014; Coombs \& Holladay, 2006, 2008) as relational history (Coombs, 2001, 2007a). As such, the following additional research questions are asked:

$\mathrm{RQ}_{2}$ : What is the extent of the two types of sports identification among the respondents of this study?

$\mathrm{RQ}_{\mathrm{b}}$ : Is either type of sports identification a predictor of stakeholders' crisis perceptions regarding NFL crises?

Wann (2006) noted that sports fans feel a personal threat to their own identity when others negatively perceive the sports entity with which they closely identify. This is because highly identified fans invest so much of themselves into their beloved sport or team and because not only do they individually identify with the team but they also socially identify with the 
other fans of the team (Wann et al., 2001). This research hypothesizes that crisis, like game losses, not only poses the same threats to sports fans' identity but also results in the same need to actively control such identity threats. As such, to complement the research questions regarding sports identification and stakeholders' crisis perceptions, and to provide directional significance to these research findings at the praxis of fandom, fanship, and crises, the following hypotheses are tested:

H1: Higher fandom will result in more positive crisis perceptions, and lower fandom will result in more negative crisis perceptions at the league, team, and athlete levels.

$\mathrm{H}_{2}$ : Higher fanship will result in more positive crisis perceptions, and lower fanship will result in more negative crisis perceptions at the league, team, and athlete levels.

\section{Method}

An online national survey was conducted with a nationally representative sample of American sports fans $(N=1,106)$. The survey instrument was launched through Qualtrics data collection services. Qualtrics offers webbased research panels for survey data collection and guarantees respondent verification, a soft watch over the initial launch, and protections against speeders and straight-liners for improved data quality. The Qualtrics survey panel respondents for this study were incentivized by awards points to complete the survey. Qualtrics handled all offers and incentives. No incentives were extended by the principal investigator.

Once the soft watch was completed, the survey launched during Week 16 of the NFL's regular season (December 20, 2017). An initial screener question asked potential respondents whether they perceived themselves to be sports fans, and only those who responded yes were welcomed to participate. Response quotas were set for each day's data collection, which occurred at different times of the day and different days of each week. Data collection concluded the week of wild card playoff games (January 8, 2018) with a total of 1,106 survey respondents.

\section{Survey Measures and Descriptive Statistics}

Each respondent's crisis perceptions regarding NFL crises, sports identification, and demographic information were captured. The stakeholders' cri- 
sis perceptions and sports-identification variables were all measured along 7-point continuous scales. Marsden and Wright (2010) in their investigation of scale ratings found that reliability levels off after 7 points, yet 7 points offers a reasonable amount of variability for analysis. The descriptive statistics are reported here among the explanations of survey measurements due to the length of inferential statistical analyses reporting in the upcoming results section.

\section{Demographics}

The mean age of respondents was 46.29 years $(S D=17.12)$. More males $(n=$ $648)$ responded to the survey than females $(n=456)$, which reflected a split of $59 \%$ and $41 \%$ on gender (see Table 1). Inclusivity of both males and females was important for this study to guard against frame errors commonly found in sports-related research (Moy \& Murphy, 2016; Spinda, 2011). That goal was achieved. Ethnic diversity was not present among respondents, as the majority (77\%) of respondents were Caucasian $(n=852)$. African Americans $(n=123)$ made up $11 \%$, Hispanic or Latinx Americans $(n=43) 4 \%$, Asian Americans $(n=27) 2 \%$, and the "other" category $(n=23)$ and no answer $(n$ $=40$ ) made up the remaining $6 \%$. Respondents were just slightly more educated than was reflected in U.S. Census data (U.S. Census, 2010), with the majority of respondents reporting that they were high school graduates $(n=$ 234), had earned a bachelor's degree $(n=294)$, or attended graduate or professional school $(n=150)$. Annual income averaged between $\$ 40 \mathrm{~K}(n=424)$ and $\$ 60 \mathrm{~K}(n=249)$.

Political measurements were captured due to the polarized nature of the \#TakeaKnee crisis. Political ideology was captured as liberal $(26 \% ; n=286)$, moderate $(43 \% ; n=475)$, and conservative $(31 \% ; n=344)$. Political partisanship resulted in Democrat $(38 \% ; n=415)$, Independent or unaffiliated $(30 \%$; $n=334)$, and Republican (32\%; $n=358)$.

\section{Crisis Perceptions}

The NFL was chosen for the context of this study on sports crises due to the nature of its highly publicized, ongoing crises (Kanski, 2016; Rodgers, 2017; Schrotenboer, 2014, 2015). To better explain, a diverse enough array of crises occurred within the NFL to offer measurement of perceptions concerning several overarching topics. The measurement of stakeholders' perceptions in relation to sports crises included four recent or ongoing 
Table 1. Demographic Descriptive Statistics

\begin{tabular}{|c|c|c|c|}
\hline & & $N$ & $\%$ \\
\hline \multirow[t]{2}{*}{ Gender $^{\mathrm{a}}$} & Male & 648 & 58.50 \\
\hline & Female & 456 & 41.20 \\
\hline \multirow[t]{4}{*}{ Ethnicity ${ }^{\mathrm{a}}$} & Caucasian & 852 & 77.00 \\
\hline & African American & 123 & 11.10 \\
\hline & Hispanic Latinx American & 43 & 3.90 \\
\hline & Asian American & 27 & 2.40 \\
\hline \multirow[t]{6}{*}{ Education } & Less than high school & 20 & 1.80 \\
\hline & High school graduate & 234 & 21.10 \\
\hline & Some college & 305 & 27.60 \\
\hline & Associate & 103 & 9.30 \\
\hline & Bachelor & 294 & 26.60 \\
\hline & Graduate & 150 & 13.60 \\
\hline \multirow[t]{7}{*}{ Income } & up to $\$ 40 \mathrm{~K}$ & 424 & 38.30 \\
\hline & $\$ 40 \mathrm{~K}-60 \mathrm{~K}$ & 249 & 22.50 \\
\hline & $\$ 60 \mathrm{~K}-80 \mathrm{~K}$ & 145 & 13.10 \\
\hline & $\$ 80 \mathrm{~K}-100 \mathrm{~K}$ & 104 & 9.40 \\
\hline & $\$ 100 \mathrm{~K}-150 \mathrm{~K}$ & 122 & 11.00 \\
\hline & $\$ 150 \mathrm{~K}-200 \mathrm{~K}$ & 31 & 2.80 \\
\hline & $\$ 200 \mathrm{~K}+$ & 28 & 2.50 \\
\hline \multirow{3}{*}{$\begin{array}{l}\text { Political } \\
\text { ideology }\end{array}$} & Liberal & 286 & 25.80 \\
\hline & Moderate & 475 & 42.90 \\
\hline & Conservative & 344 & 31.10 \\
\hline \multirow{3}{*}{$\begin{array}{l}\text { Political } \\
\text { partisanship }^{\text {a }}\end{array}$} & Democrat & 415 & 37.50 \\
\hline & Independent & 334 & 30.20 \\
\hline & Republican & 358 & 32.30 \\
\hline
\end{tabular}

${ }^{\text {a }}$ Dummy-coded variable for subsequent analyses: gender, male $=1$, female $=0$; ethnicity, Caucasian $=1$, all else $=0$; political ideology, conservative $=1$, all else $=0$; political partisanship, Republican $=1$, all else $=0$. 
NFL crises: CTE (chronic traumatic encephalopathy), football's concussion crisis; Deflategate, a cheating accusation involving NFL's top quarterback Tom Brady and his team the New England Patriots; Ezekiel Elliot, the latest NFL athlete accused of domestic assault; and the \#TakeaKnee social-justice movement originally initiated by Colin Kaepernick and Eric Reid during the 2016 season and publicly denounced during the 2017 season by the president of the United States. Survey respondents were asked about their familiarity with the four crises and then asked whether they had discussed any of the four crises with others. Respondents were asked to select all crises they had heard about and talked about, and then they were asked to select the one crisis they had discussed with others the most.

Crisis attribution was measured by first asking respondents at which level-the macro (league), meso (team), or micro (athlete)-they attributed blame for the crisis into which they had self-selected. These sportsorganization levels were especially key in measuring the amount of blame attribution and more precisely measuring each component of crisis responsibility (see Table 2). Respondents reported attributing crisis at the league level $(n=417)$, team level $(n=136)$, and the athlete level $(n=487)$. They were also asked to what degree or how much blame they placed at the level they selected. Respondents reported placing strong amounts of blame on the league ( $n=417, M=5.42, S D=1.68)$, team $(n=136, M=5.14, S D=1.83)$, and athlete ( $n=487, M=5.82, S D=1.79$ ) levels. Other crisis responsibility components were measured, including the amount of evidence present at the selected level (league: $n=417, M=4.76, S D=1.97$; team: $n=136, M=4.96, S D$ $=1.72$; and athlete: $n=487, M=5.96, S D=1.57)$ and whether the crisis was accidental or intentional (league: $n=416, M=4.60, S D=2.01$; team: $n=135$, $M=4.83, S D=1.93$; and athlete: $n=486, M=5.99, S D=1.69$ ).

Crisis history was measured by asking respondents how often such crises occurred in the NFL (at each level), from just one time to once in a series of events (league: $n=416, M=5.00, S D=1.84$; team: $n=133, M=4.68, S D$ $=1.82$; and athlete: $n=486, M=5.29, S D=1.79$ ). Following a series of factor analyses conducted on the crisis-perception measurement items at each level and achievement of acceptable internal consistency across all three respective levels (league $[a=.70]$, team $[a=.82]$, and athlete $[a=.79]$ ), each level's crisis-perception measurements were combined to create a crisisperception scale.

The overall crisis perceptions for league were $415(M=4.94, S D=1.36)$, overall crisis perceptions for team were $133(M=4.92, S D=1.47)$, and overall crisis perceptions for athlete were $486(M=5.77, S D=1.33)$. The higher the 
Table 2. Crisis-Perception Descriptive Statistics and Scales

\begin{tabular}{|c|c|c|c|}
\hline & & $N$ & $\%$ \\
\hline \multirow[t]{5}{*}{ NFL crisis } & CTE & 214 & 19.3 \\
\hline & Deflategate & 133 & 12 \\
\hline & Elliot | DV & 47 & 4.2 \\
\hline & \#TakeaKnee & 570 & 51.5 \\
\hline & Missing & 143 & 12.9 \\
\hline \multirow[t]{5}{*}{ Blame placement } & League & 417 & 37.7 \\
\hline & Team & 136 & 12.3 \\
\hline & Athlete & 487 & 44 \\
\hline & Missing & 67 & 6.1 \\
\hline & $N$ & $M$ & $S D$ \\
\hline Blame amount league & 417 & 5.42 & 1.68 \\
\hline Blame amount team & 136 & 5.14 & 1.83 \\
\hline Blame amount athlete & 487 & 5.82 & 1.79 \\
\hline Evidence amount league & 417 & 4.76 & 1.97 \\
\hline Evidence amount team & 136 & 4.96 & 1.72 \\
\hline Evidence amount athlete & 487 & 5.98 & 1.57 \\
\hline Accidental-intentional league & 416 & 4.60 & 2.01 \\
\hline Accidental-intentional team & 135 & 4.83 & 1.93 \\
\hline Accidental-intentional athlete & 486 & 5.99 & 1.69 \\
\hline One time or series league & 416 & 5.00 & 1.84 \\
\hline One time or series team & 133 & 4.68 & 1.82 \\
\hline One time or series athlete & 486 & 5.29 & 1.79 \\
\hline $\begin{array}{l}\text { CRISIS SCALES } \\
.\end{array}$ & $N$ & $\begin{array}{l}M \\
\cdots \ldots\end{array}$ & $S D$ \\
\hline Crisis perceptions league & 415 & 4.94 & 1.36 \\
\hline Crisis perceptions team & 133 & 4.92 & 1.47 \\
\hline Crisis perceptions athlete & 486 & 5.77 & 1.33 \\
\hline
\end{tabular}


mean, the more negative the stakeholders' crisis perceptions, which means that at all three levels, stakeholders' perceptions were more negative than positive and that stakeholders' crisis perceptions were the most negative at the athlete level. Inferential statistics are reported in the results section later, but first a continuation of the other measures and each measure's descriptive statistics for scale creation will be presented.

\section{Sports Identification}

Fandom and fanship were both measured to identify the social and individual connectedness to sport felt by each respondent (Reysen \& Branscombe, 2010; Spinda, 2011; Wann \& Branscombe, 1993). Fandom was measured by adapting the Reysen and Branscombe (2010) scale that resulted in an eightitem scale (see Table 3 for full list of items). The results of these measures are reported after explaining the fanship scale, which follows next. This break in reporting measurement results is so the two types of identification can be compared and contrasted to ensure reliability, validity, and most importantly, face validity, for the social and individual dichotomy of sports identification.

Fanship was conceptualized as the individual identification between a person and his or her favorite team and measured by adapting the SSIS scale (Wann \& Branscombe, 1990, 1993). Respondents were first asked to select a favorite NFL team from a drop-down list of all 32 teams (Spinda, 2011). Then, the seven-item adapted SSIS scale questions were asked with the favorite NFL team inserted into each question. If a respondent answered "no favorite NFL team" $(n=116)$, the respondent was subsequently offered general sports-fanship and fan-behavior questions instead of the team-specific questions all other respondents who selected a favorite team received. Not surprisingly, those who answered that they favored no NFL team $(M=2.59$, $S D=1.79)$ reported lower identification.

A factor analysis was conducted to test the fandom and fanship measures for any overlap of factor loadings. Overall, the factor analysis (KMO = .95, $p<.001, d f=105$ ) of all fifteen items loaded on two factors accounting for $55 \%$ and $69 \%$ cumulative variance. The promax rotation clearly separated the fandom measurements from the fanship measurements, with principalaxis factors ranging from .70 to .89 for fandom and from .61 to .91 for fanship (threshold was set at .60 per Carpenter [2018] recommendations). Cronbach's alphas were additionally assessed to test the internal consistency 
Table 3. Sports-Identification Descriptive Statistics and Scales

\begin{tabular}{|c|c|c|c|}
\hline & $N$ & $M$ & $S D$ \\
\hline $\begin{array}{l}\text { I changed my work schedule to accommodate my } \\
\text { interest in sport. }\end{array}$ & 1106 & 2.69 & 2.11 \\
\hline I would spend all my money on sport if I could. & 1105 & 2.22 & 1.84 \\
\hline I want everyone to know I am connected to sport. & 1106 & 3.24 & 2.08 \\
\hline When sports are popular, I feel great. & 1104 & 3.49 & 2.09 \\
\hline I feel a purposeful connection to sport. & 1106 & 3.68 & 2.16 \\
\hline I strongly identify with sport. & 1106 & 3.93 & 2.18 \\
\hline I would devote all my time to sport if I could. & 1106 & 2.82 & 2.04 \\
\hline $\begin{array}{l}\text { I want to be friends with others who also enjoy } \\
\text { sport. }\end{array}$ & 1106 & 4.16 & 2.10 \\
\hline Fandom scale & 1100 & 3.28 & 1.78 \\
\hline $\begin{array}{l}\text { How important is it to you that your favorite NFL } \\
\text { team wins? }\end{array}$ & 991 & 5.35 & 1.72 \\
\hline $\begin{array}{l}\text { How strongly do you see yourself as a fan of your } \\
\text { favorite NFL team? }\end{array}$ & 991 & 5.36 & 1.69 \\
\hline $\begin{array}{l}\text { How closely do you follow (via news, social media, } \\
\text { etc.) your favorite NFL team? }\end{array}$ & 991 & 4.78 & 1.87 \\
\hline $\begin{array}{l}\text { How strongly do your friends see you as a fan of } \\
\text { your favorite NFL team? }\end{array}$ & 990 & 4.86 & 1.92 \\
\hline $\begin{array}{l}\text { How important is being a fan of your favorite NFL } \\
\text { team? }\end{array}$ & 991 & 4.81 & 1.90 \\
\hline $\begin{array}{l}\text { How much do you dislike your favorite NFL } \\
\text { team's rivals? }\end{array}$ & 991 & 4.29 & 2.05 \\
\hline $\begin{array}{l}\text { How much do you display your favorite NFL } \\
\text { team's name or logo where you live or work or on } \\
\text { your clothing? }\end{array}$ & 991 & 4.16 & 2.12 \\
\hline Fanship scale & 990 & 4.80 & 1.61 \\
\hline
\end{tabular}

and reliability of the fandom measures $(a=.95)$ and the fanship measures $(a$ $=.93$ ), respectively. Resultantly, the items were transformed into scales for each sports-identification measurement: the fandom scale $(n=1,100, M=$ $3.28, S D=1.78)$ and the fanship scale $(n=990, M=4.80, S D=1.61)$.

I84 Journal of Sports Media, Vol. I4, Nos. I-2, Spring-Fall 2019 


\section{Results}

RQ1 explored the degree to which the four NFL crises were perceived by NFL stakeholders. Overall, the majority of respondents (52\%) reported knowing about and talking most about the \#TakeaKnee crisis $(n=570)$. The second most commonly selected crisis was CTE (19\%; $n=214)$, followed by Deflategate $(12 \% ; n=133)$, and the smallest number of respondents reported knowing and communicating about the Ezekiel Elliot domestic assault crisis $(4 \% ; n=47)$. The remaining respondents $(13 \% ; n=143)$ did not report knowing or talking about NFL crises and were therefore skipped forward in the survey to complete the demographic information. See Table 2 for all crisis perceptions-related results.

Crisis attribution was measured by asking respondents which level of the NFL-league, team, or athlete-they felt were responsible for the incident they selected as the crisis they had heard and communicated about most frequently. Findings indicate that stakeholders' felt that athletes were most often to blame (44\%), the league came in as a close second (37.7\%), and teamlevel blame attribution was reported the least often (12.3\%), which suggests that sports identification could provide a protective layer regarding blame attribution.

Crisis perceptions were overall more negative than positive across all three levels of blame attribution. To summarize the scales for crisis perceptions at each level, the overall crisis perceptions for the league $(n=415, M=$ $4.94, S D=1.36)$ and the team level $(n=133, M=4.92, S D=1.47)$ were moderately negative, and the two were quite similar in strength. However, overall crisis perceptions for the athlete level $(n=486, M=5.77, S D=1.33)$ were much more negative. These results indicate that stakeholders' attribution of blame coincided with negative crisis perceptions (Coombs, 2004, 2007b) and were more likely attributed, and more negatively so, at the league and athlete levels than at the team level.

This research argued for analysis of crisis attribution and perceptions at the team level to expand current research within the sports crisis literature. Few stakeholders opted into crisis attribution at the team level, and those who did showed no significance in variation of their crisis perceptions. Taken together, these findings at the team level note optimistic inquiry for sports-identification measurement in relation to sport crises because team identification (i.e., fanship) could be why there was a lack of willingness to attribute crisis blame at the team level. 


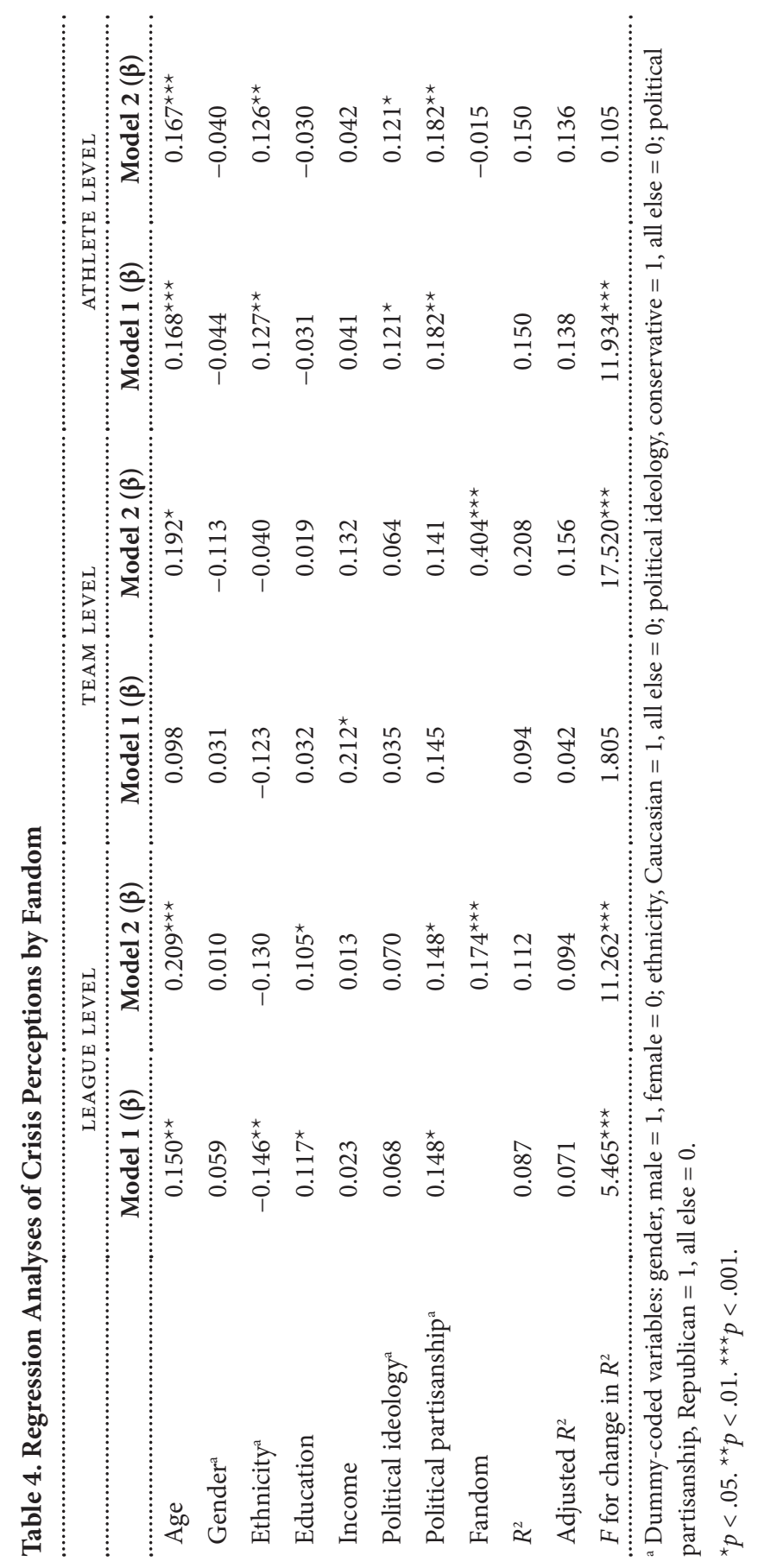




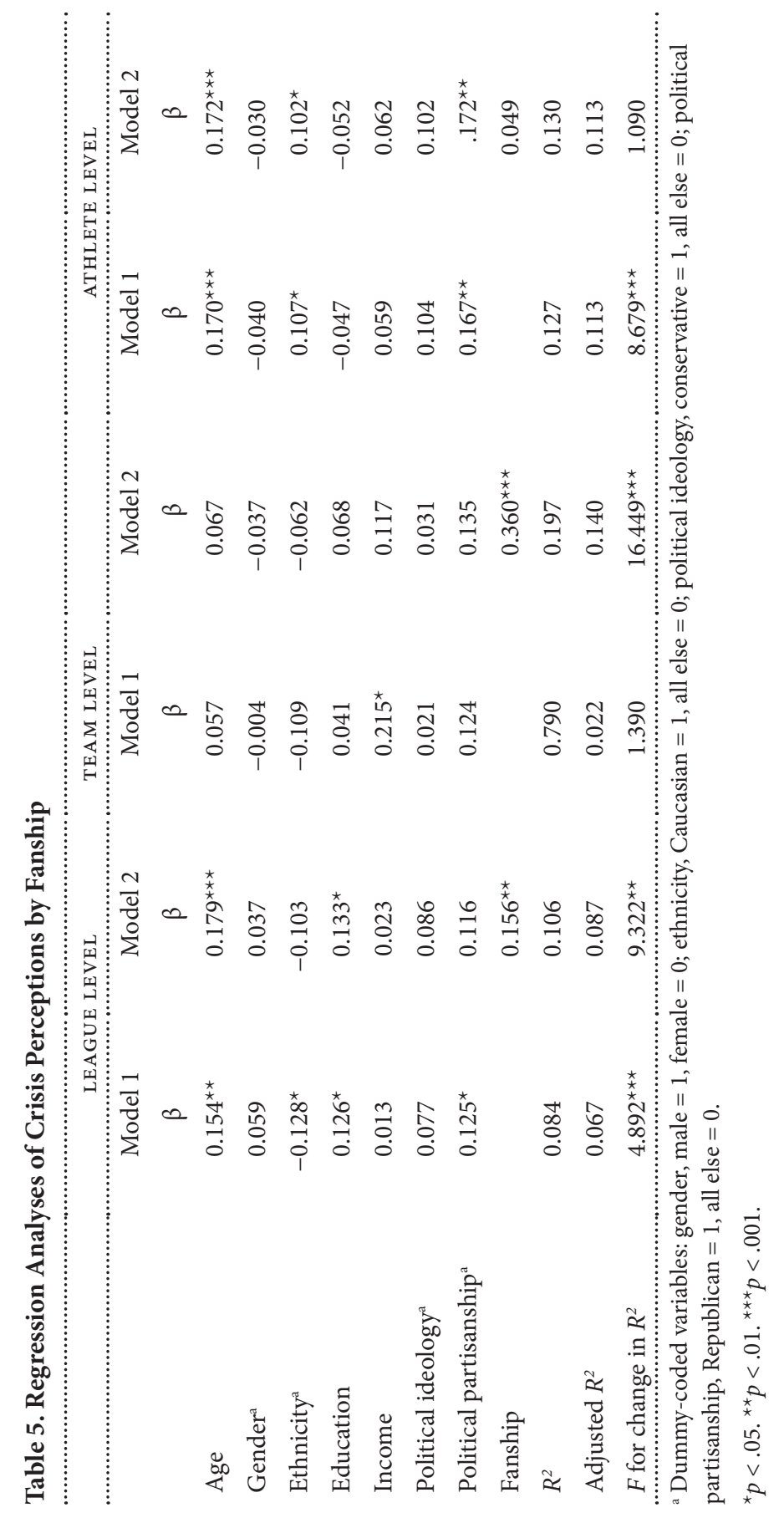




\section{Sports Identification}

To address RQ 2 , the extent of NFL stakeholders' sports identification, both fandom and fanship, was measured. The fandom scale $(n=1,100, M=3.28$, $S D=1.78)$ revealed relatively weak social identification with sport. The fanship scale $(n=990, M=4.80, S D=1.61)$ revealed moderate NFL team identification. For a full listing of descriptive statistics for sports identification see Table 3 .

$\mathrm{RQ} 2_{\mathrm{b}}$ asked whether sports identification is a predictor of crisis perceptions. To address this research question, a series of linear regression analyses were conducted. Fandom was examined for crisis perceptions at each of the three levels of the NFL organization (i.e., league, team, and athlete). Fanship then underwent the same series of analyses. All regressions controlled for stakeholders' demographic information. Results are reported in Table 4 for fandom and Table 5 for fanship.

Fandom was a significant predictor of crisis perceptions at the league and team levels but not at the athlete level. To explain, fandom $(\beta=.174, p<.001)$ was a significant predictor for crisis perceptions at the league level, $F(8,409)$ $=6.31, p<.001, R^{2}=.11, R_{\text {Adjusted }}^{2}=.09$. The demographic predictors for crisis perceptions at the league level included older, nonwhite stakeholders who were educated Republicans. At the team level, fandom $(\beta=.404, p<.001)$ was again a significant predictor for crisis perceptions, $F(8,129)=3.98, p<$ $.001, R^{2}=.20, R_{\text {Adjusted }}^{2}=.14$; and the only demographic predictor was age $(\beta$ $=.192, p<.05)$. At the athlete level, fandom was not a predictor of crisis perceptions, but older white conservative Republicans were most likely to report negative crisis perceptions at this level.

Fandom was a significant predictor of crisis perceptions at the league and team levels. Additionally, these analyses statistically collaborate with the political polarization among the \#TakeaKnee crisis for those who attributed crisis blame at the athlete level. Next is a look at fanship as a predictor of stakeholders' crisis perceptions.

Fanship $(\beta=.156, p<.01)$ was a significant predictor of crisis perceptions at the league level, $F(8,381)=5.54, p<.001, R^{2}=.11, R_{\text {Adjusted }}^{2}=.09$. Demographics also indicate that age and education were predictors of crisis perceptions at this level. At the team level, fanship $(\beta=.360, p<.001)$ was again a significant predictor of crisis perceptions, $F(8,120)=3.44, p<.01, R^{2}=.20$, $R_{\text {Adjusted }}^{2}=.14$; and it was the sole predictor at the team level. At the athlete level, fanship was not a predictor of crisis perceptions, but older white conservative Republicans were again those most likely to report negative crisis perceptions at this level. 
To answer $\mathrm{RQ}_{2}$, fandom and fanship were influential predictors of crisis perceptions, but only in certain instances. At the league level and the team level, both fandom and fanship were significant predictors of crisis perceptions. Moreover, fanship was the sole predictor (meaning no social demographics were significant) for crisis perceptions at the team level. And finally, none of the regression analyses at the athlete level found fandom or fanship to be predictors of crisis perceptions.

\section{Directional Significance of Sports Identification on Crisis Perceptions}

The associations and predictability of sports identification and stakeholders' crisis perceptions have been identified, but the directional hypotheses relating to these variables remain to be tested. $\mathrm{H}_{1}$ and $\mathrm{H}_{2}$ posited that higher amounts of fandom and fanship result in more positive crisis perceptions by stakeholders.

Fandom. H1 posited that higher fandom would result in more positive crisis perceptions and that lower fandom would result in negative crisis perceptions. H1 was not fully supported, because fandom did not significantly statistically differ at the league level or athlete level. At the team level, however, results significantly statistically differed but in the opposite direction hypothesized. For example, crisis perceptions were less negative $(M=4.39)$ among stakeholders who reported lower fandom $(\leq 3.28)$, not higher fandom. In fact, crisis perceptions were more negative $(M=5.32)$ among those who reported higher fandom $(\geq 3.28), t=3.8, d f=130, p<.001$.

Cumulatively, fans who reported higher amounts of social identification with sport reported more negative crisis perceptions, but only at the team level were those differences statistically significant. Next, the same series of hypothesis testing is reported for fanship, or individual identification, and stakeholders' crisis perceptions.

Fanship. $\mathrm{H}_{2}$ posited that higher fanship would result in more positive crisis perceptions and that lower fanship would result in more negative crisis perceptions. $\mathrm{H}_{2}$ was not fully supported, because just as was identified in the fandom analyses, sports identification and stakeholders' crisis perceptions leaned the opposite direction hypothesized. At the league level, crisis perceptions were less negative $(M=4.75)$ among stakeholders who reported lower fanship $(\leq 4.80)$ and were more negative $(M=5.07)$ among those who reported higher fanship $(\geq 4.80), t=2.27, d f=382, p<.05$.

At the team level, once again crisis perceptions were less negative $(M$ $=4.39)$ among stakeholders who reported lower fanship $(\leq 4.80)$ and were 
more negative $(M=5.25)$ among those who reported higher fanship $(\geq 4.80)$, $t=3.14, d f=121, p<.01$.

Resultantly, those who reported higher individual identification with sport reported more negative crisis perceptions at the league and team levels of crisis attribution. To sum up this section of hypothesis testing, the team level was statistically significant for both fandom's and fanship's propensity to calibrate stakeholders' crisis perceptions, and the league level was only statistically significant for fanship's propensity to calibrate stakeholders' crisis perceptions. At the athlete level, neither fandom nor fanship differed significantly among stakeholders' crisis perceptions, but results for both at the athlete level tracked the direction hypothesized. To elaborate, at the athlete level, sports fans with higher identification recorded less negative crisis perceptions. Respondents who reported less sports identification and attributed blame at the athlete level perceived NFL crises more negatively.

It is important to additionally note that no statistically significant results were found among crisis perceptions and favorite team. In other words, sports fans did not often select their own favorite team's crisis; and when they did, the blame was shifted away from the team. Patriots fans offered the best example of this occurrence. Patriots fans who selected Deflategate $(n=24)$ placed blame on the league $(n=20)$ but not on the Patriots team $(n$ $=2$ ) or Tom Brady $(n=2)$. This finding supports past rhetorical research that athlete-level transgressions result in transferred negative stakeholders' crisis perceptions to the league when corrective actions are not widely accepted by stakeholders. Kruse's (1981) earlier research posited that fans possess an innate need to close a crisis-induced dissonance gap when a crisis involving a favorite athlete or beloved team occurs. This research suggests that blame transfer is an attempt at meeting this need among fans who highly identify with sport.

\section{Discussion}

This research examined the relationship between stakeholders' crisis perceptions and sports identification. This application of sports identification as relational history (Coombs, 2001) and the pairing of sports identification with sports-specific crises was an important bridge to span for the sports and crisis communication literatures. The theoretical adherence of situational crisis communication theory to sports crises was tested through the underlying assumption that a positive relational history results in less negative perceptions of crisis. This combination was examined by measuring both social identification (fandom) and individual identification (fan- 
ship) and testing each statistically for influence on crisis perceptions at three structural levels-league, team, and athlete-of a sports organization (NFL). Sports crisis and sports identification at the team level resulted in the strongest and most consistent significant findings. Directional significance further indicates that sports crises are perceived similarly to general sports rivalry and not simply to the direct connectedness to one's beloved team as originally hypothesized at the onset of this research. These findings substantiate the extension of the situational crisis communication theory model to include fandom and fanship as an influential relational history assessment factor, and this research highlights the importance of coupling identification with crisis perceptions in sports-related crises.

\section{Stakeholders' Crisis Perceptions}

The first research question investigated NFL stakeholders' subjective knowledge of four NFL-related crises and asked stakeholders their perceptions concerning those crises. NFL stakeholders' crisis perceptions were overall more negative than positive across all three levels of blame attribution. The findings of this research suggest that stakeholders' perceptions are perhaps siloed within organizational structural levels and differ across the continuum of positive to negative perceptions among those levels of blame placement. Additionally, blame attribution occurred the least at the team level, and no statistical significance was reached among respondents who chose to discuss a crisis that directly related to their own favorite team. These findings collectively suggest that identification plays some sort of role in calibrating crisis perceptions.

This research, along with prior research, suggests that blame transfer occurs in at least two ways across the siloed structural levels in a sports organization. The first is due to the structure of the NFL as a sports league, which aided in compartmentalizing crisis with a damming effect until crisis history increased, at which time the proverbial dam broke. To explain, when an athlete is involved in a domestic assault case, blame is placed on the athlete. When domestic assault repeatedly occurs and several athletes are implicated with similar yet separate charges, attribution begins to shift from the athlete to the league (Moritz, 2016). That same shift is suggested with the \#TakeaKnee social movement. The blame placement in this research for the \#TakeaKnee crisis resulted in a split among league-level and athlete-level blame placement. This was likely a result of the multiple times athletes protested police brutality by kneeling during the national anthem 
and of the league allowing the protests to continue through the end of the season. Kruse $(1977,1981)$ suggested that fans possess an innate need to close a cognitive dissonance gap when a favorite team or athlete is involved in some sort of wrongdoing. Disciplinary action aids in closing that gap. Alternatively, the absence of disciplinary action or the more often the league allows the affliction to occur, the more the attribution of blame then shifts to the league.

The second way in which blame transfer was suggested in the current data was in regard to the Deflategate crisis. Although Tom Brady was accused of ordering team members to deflate footballs, Patriots fans significantly more often transferred blame to the league and not to the team or to the athlete. Similar to the aforementioned crisis-induced dissonance gap, the blame shifting in the case of Deflategate was likely due to a sports fan's propensity to feel a personal threat to their own identity when others negatively perceive the sports entity with which they closely identify (Wann, 2006).

These research results suggest that blame placement should be consistently assessed across the structural levels of a sports organization in future sports crisis research investigations. These findings also suggest that identification plays a role in calibrating stakeholders' crisis perceptions, which is discussed next.

\section{Sports Identification and Crisis Perceptions}

Personal experiences contribute to personal identification (Hirt \& Clarkson, 2011). Identification has been noted to span along a continuum from no identification at all to high identification and close connectedness (Gantz et al., 2006; Wann \& Branscombe, 1993). Some social psychologists claim there is a state-versus-trait component but base those arguments mostly on the duration and strength of being a fan (Wann 2006; Wann et al., 2001), while other communication scholars have sought the underlying personality traits of being a sports fan (Brown-Devlin et al., 2017). Even a "primary social identity" has been noted in connection with sports identification, which has additionally included an "emphasis on emotion over knowledge" (Hirt \& Clarkson, 2011, pp. 2-3). Be it endurance or emotion or otherwise, some component of connectedness undeniably exists between sports fans and their favored sports entity. Researchers have been mostly remiss in measuring sports identification alongside stakeholders' perceptions of sports crises, however. This research filled that gap.

192 Journal of Sports Media, Vol. I4, Nos. I-2, Spring-Fall 2019 
The assessment component from the situational crisis communication theory model, relational history, was tested in this research as sports identification to answer the second research question and remaining research hypotheses. Situational crisis communication theory suggests that a prior positive relationship can provide buffers or halos in crisis assessment, therefore reducing negative perceptions of crisis (Coombs, 2007a; Coombs \& Holladay, 2006; Koerber \& Zabara, 2017). Sports communication research defines relationship with sport as sports identification and assesses sports identification using two broad and interchangeable terms: fandom and fanship. This research argued for a dichotomous investigation into both social (fandom) and individual (fanship) sports identification with an intentional effort to tease out how either or both may or may not be influencing components of stakeholders' crisis perceptions regarding sports-related crises. Overall, sports identification was not extreme among the respondents of this survey. Fandom was at or slightly below the median point across the three levels of crisis attribution, and fanship was moderately high. Still, fandom and fanship were associated with stakeholders' perceptions and even calibrated stakeholders' perceptions in relation to NFL crises. The fact that predictability existed among the variables was an important breakthrough in sports crisis communication research.

\section{Crisis Perceptions as Sports Rivalry}

Hypotheses speculated that higher levels of fandom or fanship would result in less negative crisis perceptions by stakeholders. Fandom, a social identity with sport, and fanship, often termed "team identification" by sports communication scholars (Billings et al., 2017; Branscombe \& Wann, 1991; Spinda, 2011), varied in associations and influential propensity among NFL stakeholders and the NFL's structural levels. Overall fandom levels were relatively weak among NFL stakeholders, but fanship was strong. Both types of sports identification held an associative influence with stakeholders' crisis perceptions, but both tracked the opposite direction than theorized and hypothesized for influential propensity.

Fandom and fanship both demonstrated an influential propensity at the league and team levels for crisis perceptions, and fanship was the sole predictor at the team level. Directional significance found that higher levels of fandom and fanship resulted in more negative crisis perceptions at the league and team levels for stakeholders. These results tracked in the opposite relational direction hypothesized, which would have connected 
identification to more positively leaning perceptions rather than negative perceptions.

The best way to explain these findings is to reach to schadenfreude (Dalakas \& Phillips Melancon, 2012; Leach, Spears, Branscombe, \& Doosje, 2003) and a fan behavior called glory out of reflective failure, or GORFing (Billings et al., 2017; Havard, 2014). The basic underlying premise of schadenfreude-which is defined as a feeling of joy at another's adversity-and GORFing is that the loss of a game by any other team is beneficial to one's own favorite team. GORFing's associative relationship with sports identification further substantiates that claim, and GORFing's conceptualization and measurement most recently consumed the affective measurements of schadenfreude (Billings et al., 2017).

In sports crises, the current research now additionally suggests that stakeholders' underlying relational history was significantly associated with negative crisis perceptions, especially at the team level, where identification was highest. Stakeholders were not significantly likely to attribute crisis to their own favorite team. Moreover, stakeholders' identification increased the propensity of negative perceptions of other teams' crises, likely because of the rivalry inherent in sport. These findings regarding the relational associations among the concept of crisis and the concept of sports identification suggest the underlying thesis that stakeholders perceive sports crises in a similar manner as they perceive game wins and losses. In other words, sports fans are feeling joyfully glorified by any other team's crisis-related demise.

Identification's role in that glorified feeling connects to both the basic conceptual components of social and individual identification, which are in-group bias and out-group derogation, as well as to attribution theory (Heider, 1958; Tajfel \& Turner, 1979; Weiner, 1986, 2008). The very basis of situational crisis communication theory is attribution theory, but just as Weiner (2008) noted when extending Heider's original work in balance and attribution theories, attribution should encompass an array of perceptionsboth negative and positive. In other words, investigations into crisis perceptions should include both positive and negative perceptions and how identification might calibrate those perceptions along that valenced continuum. In concurrence, this research suggests such a shift in the way stakeholders' perceptions of sports crises are approached. Crises have been approached as a continuum of severity in negative perceptions only, but in sport something slightly different is occurring.

This research filled a gap in the sports communication and crisis communication bodies of literature. Limitations exist, as in any social science;

I94 Journal of Sports Media, Vol. I4, Nos. I-2, Spring-Fall 2019 
but this first step in the measurement of stakeholders' perceptions in response to an array of crises across a sports organization's operational levels provides much deeper knowledge regarding sports fans' crisis perceptions than has been identified before. Future research should continue this investigation across the three structural levels of sports organizations and continue to build more precise crisis-perception measurements for each level. The fact that the athlete level yielded no significance in relation to sports identification is imperative to further exploration. Future research should investigate how sports identification as a predictor of crisis perceptions might differ between team sports versus more individualized sports such as tennis or golf. Future sports crisis research also should immediately and comprehensively include the parallelism of perceptions relating to sportsrelated crises and sports rivalry.

In conclusion, sports identification was found to be an associative influencer of stakeholders' perceptions regarding sports crises. Fandom and fanship were both indicators of influence at the team level, and a closer look revealed that the influence tracked in the opposite direction hypothesized within crisis communication theory. The directional discrepancy in this research suggests that the power of team rivalry extends beyond game outcomes to include crises-even crises that possess social and moral implications.

Jennifer Harker is an assistant professor of strategic communication in the Reed College of Media at West Virginia University. Dr. Harker researches stakeholder perceptions, crisis communication, and networks.

\section{References}

Avery, E. J., Lariscy, R. W., Kim, S., \& Hocke, T. (2010). A quantitative review of crisis communication research in public relations from 1991 to 2009. Public Relations Review, 36(2), 190-192. https://doi.org/10.1016/j.pubrev.2010.01.001

Benoit, W. L. (2015). Accounts, excuses, and apologies: Image repair theory and research (2nd ed.). Albany, NY: State University of New York Press.

Billings, A. C., Coombs, W. T., \& Brown, K. A. (2018). Reputational challenges in sport: Theory and application. New York, NY: Routledge.

Billings, A. C., Qiao, F., Brown, K. A., \& Devlin, M. (2017). Of sports and schadenfreude: Fandom, rival successes and failures, and the introduction of glory out of reflected failure measurements. In A. C. Billings \& K. A. Brown (Eds.), Evolution of the modern sports fan: Communicative approaches (pp. 65-83). London, England: Lexington Books. 
Branscombe, N. R., \& Wann, D. L. (1991). The positive social and self concept consequences of sports team identification. Journal of Sport and Social Issues, 15(2), 115-127. https://doi.org/10.1177/019372359101500202

Brown, N. A., \& Billings, A. C. (2013). Sports fans as crisis communicators on social media websites. Public Relations Review, 39(1), 74-81. https://doi.org/10.1016/j .pubrev.2012.09.012

Brown, W. J. (2015). Examining four processes of audience involvement with media personae: Transportation, parasocial interaction, identification, and worship. Communication Theory, 25(3), 259-328. https://doi.org/10.1111/comt.12053

Brown-Devlin, N., Devlin, M. B., \& Vaughan, P. W. (2017). Why fans act that way: Using individual personality to predict BIRGing and CORFing behaviors. Communication and Sport. https://doi.org/10.1177/2167479517725011

Carpenter, S. (2018). Ten steps in scale development and reporting: A guide for researchers. Communication Methods and Measures, 12(1), 25-44. https://doi.org /10.1080/19312458.2017.1396583

Cialdini, R. B., \& Richardson, K. D. (1980). Two indirect tactics of image management: Basking and blasting. Journal of Personality and Social Psychology, 39(3), 406-415. https://doi.org/10.1037/0022-3514.39.3.406

Coombs, W. T. (1995). Choosing the right words: The development of guidelines for the selection of the "appropriate" crisis-response strategies. Mass Communication Quarterly, 8(4), 447-474. https://doi.org/10.1177/0893318995008004003

Coombs, W. T. (1998). An analytic framework for crisis situations: Better responses from a better understanding of the situation. Journal of Public Relations Research, 10(3), 177-191. https://doi.org/10.1207/s1532754xjprr1003_02

Coombs, W. T. (2001). Crisis management: Advantages of a relational perspective. In J. A. Ledingham \& S. D. Bruning (Eds.), Public relations as relationship management: A relational approach to the study and practice of public relations (pp. 73-94). Mahwah, NJ: Lawrence Erlbaum Associates.

Coombs, W. T. (2004). Impact of past crises on current crisis communication: Insights from situational crisis communication theory. Journal of Business Communication, 41(3), 265-289. https://doi.org/10.1177/0021943604265607

Coombs, W. T. (2007a). Protecting organization reputations during a crisis: The development and application of situational crisis communication theory. Corporate Reputation Review, 10(3), 163-176. https://doi.org/10.1057/palgrave.crr .1550049

Coombs, W. T. (2007b). Attribution theory as a guide for post-crisis communication research. Public Relations Review, 33(2), 135-139. https://doi.org/10.1016/j .pubrev.2006.11.016

Coombs, W. T. (2014). Ongoing crisis communication: Planning, managing, and responding. Thousand Oaks, CA: Sage. 
Coombs, W. T., \& Holladay, S. J. (1996). Communication and attributions in a crisis: An experimental study in crisis communication. Journal of Public Relations Research, 8(4), 279-295. Available at http://www.tandfonline.com/toc/hprr2o /current\#.VSCYXZVFDIU

Coombs, W. T., \& Holladay, S. J. (2002). Helping crisis managers protect reputational assets: Initial tests of the situational crisis communication theory. Management Communication Quarterly, 16(2), 165-186. https://doi.org/10.1177 /o89331802237233

Coombs, W. T., \& Holladay, S. J. (2006). Unpacking the halo effect: Reputation and crisis management. Journal of Communication Management, 1o(2), 123-137. https://doi.org/10.1108/13632540610664698

Coombs, W. T., \& Holladay, S. J. (2008). Comparing apology to equivalent crisis response strategies: Clarifying apology's role and value in crisis communication. Public Relations Review, 34(3), 252-257. https://doi.org/10.1016/j.pubrev.2008.04 .001

Dalakas, V., \& Phillips Melancon, J. (2012). Fan identification, schadenfreude toward hated rivals, and the mediating effects of Importance of Winning Index (IWIN). Journal of Services Marketing, 26(1), 51-59. https://doi.org/10.1108 lo8876041211199724

Dietz-Uhler, B., \& Murrell, A. (1999). Examining fan reactions to game outcomes: A longitudinal study of social identity. Journal of Sport Behavior, 22(1), 15-27. Retrieved from http://libproxy.lib.unc.edu/login?url=https://search.proquest.com /docview/215876024?accountid=14244

Gantz, W., Wang, Z., Paul, B., \& Potter, R. F. (2006). Sports versus all comers: Comparing TV sports fans with fans of other programming genres. Journal of Broadcasting and Electronic Media, 50(1), 95-118. https://doi.org/10.1207 /s15506878jobem5001_6

Harker, J. L., \& Saffer, A. J. (2018). Mapping a subfield's sociology of science: A 25year network and bibliometric analysis of the knowledge construction of sport crisis communication. Journal of Sports and Social Issues, 42 (5), 369-392. https:// doi.org/10.1177/0193723518790011

Havard, C. T. (2014). Glory out of reflected failure: The examination of how rivalry affects sport fans. Sport Management Review, 17(3), 243-253. https://doi.org/10 $.1016 /$ j.smr.2013.09.002

Heider, F. (1958). The psychology of interpersonal relations. New York, NY: Wiley.

Hirt, E. R., \& Clarkson, J. J. (2011). The psychology of fandom: Understanding the etiology, motives, and implications of fanship. In L. R. Kahle \& A. G. Close (Eds.), Consumer Behavior Knowledge for Effective Sports and Event Marketing (pp. 59-85). New York, NY: Routledge.

Kanski, A. (2016, September 9). Why the NFL's reputation is bulletproof. Retrieved from http://www.prweek.com/article/1408484/why-nfls-reputation-bulletproof 
Koerber, D., \& Zabara, N. (2017). Preventing damage: The psychology of crisis communication buffers in organized sports. Public Relations Review, 43(1), 193-200. https://doi.org/10.1016/j.pubrev.2016.12.002

Kruse, N. W. (1977). Motivational factors in non-denial apologia. Central States Speech Journal, 28(1), 13-23. https://doi.org/10.1080/10510977709367915

Kruse, N. (1981). Apologia in team sport. Quarterly Journal of Speech, 67(3), 270283. https://doi.org/10.1080/00335638109383572

Leach, C. W., Spears, R., Branscombe, N. R., \& Doosje, B. (2003). Malicious pleasure: Schadenfreude at the suffering of another group. Journal of Personality and Social Psychology, 84(5), 932-943. https://doi.org/10.1037/oo22-3514.84.5.932

L'Etang, J. (2006). Public relations and sport in promotional culture. Public Relations Review, 32(4), 386-394. https://doi.org/10.1016/j.pubrev.2006.09.006

L'Etang, J. (2013). Sports public relations. London, England: Sage.

L'Etang, J., \& Hopwood, M. (2008) Sports public relations. Public Relations Review, 34(2), 87-89. https://doi.org/10.1016/j.pubrev.2008.05.001

Marsden, P. V., \& Wright, J. D. (2010). Handbook of survey research. West Yorkshire, England: Emerald Group.

Moritz, B. P. (2016). Evolution of a modern sports scandal. In H. Mandell \& G. M. Chen (Eds.), Scandal in the digital age (pp. 185-199). New York, NY: Springer.

Moy, P., \& Murphy, J. (2016). Problems and prospects in survey research. Journalism and Mass Communication Quarterly, 93(1), 16-37. https://doi.org/10.1177 /1077699016631108

Moyer-Gusé, E. (2015). Extending the examination of audience involvement with media personae: Response to Brown. Communication Theory, 25(3), 284-289. https://doi.org/10.1111/comt.12071

Reysen, S., \& Branscombe, N. R. (2010). Fanship and fandom: Comparisons between sport and non-sport fans. Journal of Sport Behavior, 33(2), 176-193. Retrieved from http://libproxy.lib.unc.edu/login?url=https://search.proquest.com /docview/215872141?accountid=14244

Rodgers, H. (2017, September 26). NFL searching for crisis communications assistant after Trump savages league. Retrieved from http://dailycaller.com/2017 /o9/26/nfl-searching-for-crisis-communications-assistant-after-trump-savages -them/

Schrotenboer, B. (2014, October 2). History of leniency: NFL domestic cases under Goodell. USA Today. Retrieved from http://www.usatoday.com/story/sports/nfl /2014/10/o1/nfl-domestic-abuse-history-under-roger-goodell/16566615/

Schrotenboer, B. (2015). NFL player arrests: Arrest database. USA Today. Retrieved from http://www.usatoday.com/sports/nfl/arrests/

Sohn, Y. J., \& Lariscy, R. W. (2012). A “buffer” or “boomerang?”-The role of corporate reputation in bad times. Communication Research, 42(2), 237-259. https:// doi.org/10.1177/0093650212466891 
Spinda, J. S. (2011). The development of basking in reflected glory (BIRGing) and cutting off reflected failure (CORFing) measures. Journal of Sport Behavior, 34(4), 392-420. Retrieved from http://libproxy.lib.unc.edu/login?url=https:// search.proquest.com/docview/903983079?accountid=14244

Tajfel, H. (1982). Social psychology of intergroup relations. Annual Review of Psychology, 33(1), 1-39. https://doi.org/10.1146/annurev.ps.33.020182.000245

Tajfel, H., \& Turner, J. C. (1979). An integrative theory of intergroup conflict. Social Psychology of Intergroup Relations, 33(47), 74.

Ulmer, R. R. (2001). Effective crisis management through established stakeholder relationships: Malden Mills as a case study. Management Communication Quarterly, 14(4), 590-615. https://doi.org/10.1177/0893318901144003

Ulmer, R. R., Seeger, M. W., \& Sellnow, T. L. (2007). Post-crisis communication and renewal: Expanding the parameters of post-crisis discourse. Public Relations Review, 33(2), 130-134. https://doi.org/10.1016/j.pubrev.2006.11.015

U.S. Census. (2010). General demographic characteristics. Retrieved from https:// factfinder.census.gov/faces/nav/jsf/pages/index.xhtml

Wann, D. L. (1995). Preliminary validation of the sport fan motivation scale. Journal of Sport and Social Issues, 19(4), 377-396. https://doi.org/10.1177 /019372395019004004

Wann, D. L. (2006). Understanding the positive social psychological benefits of sport team identification: The team identification-social psychological health model. Group Dynamics: Theory, Research, and Practice, 10(4), 272-296. https:// doi.org/10.1037/1089-2699.10.4.272

Wann, D. L., \& Branscombe, N. R. (1990). Die-hard and fair-weather fans: Effects of identification on BIRGing and CORFing tendencies. Journal of Sport and Social issues, 14(2), 103-117. https://doi.org/10.1177/019372359001400203

Wann, D. L., \& Branscombe, N. R. (1993). Sports fans: Measuring degree of identification with their team. International Journal of Sport Psychology, 24(1), 1-17.

Wann, D. L., Melnick, M. J., Russell, G. W., \& Pease, D. G. (2001). Sport fans: The psychology and social impact of spectators. New York, NY: Routledge.

Weiner, B. (1986). An attributional theory of motivation and emotion. New York, NY: Springer-Verlag.

Weiner, B. (2008). Reflections on the history of attribution theory and research: People, personalities, publications, problems. Social Psychology, 39(3), 151-156. https://doi.org/10.1027/1864-9335.39.3.151 